\title{
Phenolic Content, Antioxidant and Antibacterial Effects of Fruit Extracts of Algerian Ash, Fraxinus excelsior
}

\author{
S. AMAMRA, N. CHAREF, L. ARRAR*, O. BELHADDAD, S. KHENNOUF , K. ZAIM² AND A. BAGHIANI ${ }^{1}$ \\ Laboratory of Applied Biochemistry, ${ }^{1}$ Laboratory of Phytotherapy Applied to Chronic Diseases, Faculty of Nature and Life \\ Sciences, ${ }^{2}$ Laboratory of Electrochemistry and Solid Energy, Faculty of Technology, University Ferhat AbbasSetif1, 19000, \\ Setif, Algeria
}

Amamra et al.: Phenolic contents, antioxidant and antibacterial effects of Algerian ash

\begin{abstract}
This study involved investigation of the antioxidant and antibacterial activities of Algerian Fraxinus excelsior extracts. Antioxidant activity was evaluated using spectrophotometric and electrochemical techniques. Phytochemical screening revealed the presence of alkaloids, tannins, polyphenols, flavonoids, sterols/triterpenes, and coumarins. The total polyphenol contents in the extracts were in the order of ethyl acetate $>$ methanol $>$ butanol $>$ chloroform $>$ aqueous $>$ petroleum ether, while flavonoid contents were in the order of, ethyl acetate>chloroform $>$ methanol $>$ butanol $>$ aqueous $>$ petroleum ether. In the 2,2'-diphenyl1-picrylhydrazyl test, ethyl acetate extract exhibited maximum activity followed by chloroform extract, methanol extract, butanol extract, aqueous extract and petroleum ether extract. $\beta$-Carotene-linoleate and metal chelation tests showed closely the same order, ethyl acetate, chloroform, methanol, butanol, aqueous and petroleum ether extracts. Antioxidant activity measured using cyclic voltammetry method demonstrated activity in the order of ethyl acetate, chloroform, methanol, butanol and aqueous while petroleum ether extract did not show any activity. Results also demonstrated that some extracts possessed antibacterial activity. In conclusion, Fraxinus excelsior extracts contain active compounds, which have antioxidant and antibacterial effects and could be useful in the treatment of pathologies where these activities are needed.
\end{abstract}

Key words: Phytochemical screening, Fraxinus excelsior L., B-carotene, antioxidant capacity, cyclic voltammetry, antibacterial effect

The human body produces reactive oxygen species (ROS) such as superoxide anion radical, hydroxyl radical and hydrogen peroxide by many enzymatic systems through oxygen consumption. In small amounts, these ROS can be beneficial as signal transducers and growth regulators ${ }^{[1]}$. However, during oxidative stress, large amounts of these ROS can be produced and may be dangerous because of their ability to attack numerous biomolecules. In fact, it has been reported that ROS contribute largely to cellular aging, mutagenesis, and coronary heart disease through several ways including membrane destabilization, DNA breakage and generally by oxidizing low-density lipoproteins ${ }^{[2]}$. The cell can reduce the impact of ROS either by an endogenous system implicating enzymes such as catalase and superoxide dismutase or by an exogenous system using antioxidants, vitamin $\mathrm{C}$ and $\alpha$-tocopherol ${ }^{[3]}$.

A great number of plants showed antioxidant and scavenger activities against free radicals ${ }^{[4]}$. This antioxidant capacity can be explored in food industry by using plants as a source of antioxidants to prevent the rancidity and oxidation of lipids. Ash (Fraxinus excelsior L.), belonging to the Oleaceae family, locally known as "l'ssanel'ousfour". It is known worldwide as an antioxidant ${ }^{[5]}$, antiinflammatory, antirheumatic ${ }^{[6]}$, analgesic and antipyretic plant ${ }^{[5]}$. It has been reported that seed extract of $F$. excelsior possessed hypoglycaemic activity ${ }^{[5]}$. In the present study, the antioxidant capacity of many extracts of $F$. excelsior was investigated using DPPH and $\beta$-carotene/linoleic acid tests and compared those with the results obtained using an electrochemical method. Antimicrobial activity was also examined and a relationship was established between these activities and the contents of polyphenols and flavonoids.

This is an open access article distributed under the terms of the Creative Commons Attribution-NonCommercial-ShareAlike 3.0 License, which allows others to remix, tweak, and build upon the work non-commercially, as long as the author is credited and the new creations are licensed under the identical terms

Accepted 21 September 2018

Revised 22 March 2018

Received 26 June 2017

Indian J Pharm Sci 2018;80(6):1021-1028 


\section{MATERIAL AND METHODS}

Fruits of F. excelsior were collected from M'sila region in the middle east of Algeria during 2010. The plants were identified in the Department of Ecology and Vegetal Biology, Faculty of Nature and Life, University Ferhat Abbas Setif1. A voucher specimen was deposited in the department under the No: DBEV/010/25593. Extractions were carried out using various polar and non-polar solvents ${ }^{[7]}$. The protocol of extraction in presented in the flow chart (fig. 1).

\section{Phytochemical analysis:}

Phytochemical tests to detect the presence of different phytoconstituents were performed according to the method described by Bruneton ${ }^{[8]}$. The tests were based on visual observation of colour changes or formation of a precipitate after the addition of specific reagents. TLC plates were sprayed with Dragendorrf's reagent, $\mathrm{AlCl}_{3}(10 \%)$ or Stiasny's reagent for the detection of alkaloids, tannins and flavonoids, respectively. Detection of anthraquinones, sterols/ triterpenes and mucilage was carried out using $\mathrm{NH}_{4} \mathrm{OH}$ $(10 \%)$, acetic anhydride, $\mathrm{H}_{2} \mathrm{SO}_{4}$ and ethanol reagents, respectively ${ }^{[9,10]}$.

\section{Determination of total polyphenols and flavonoids}

Total phenol content was determined using the FolinCiocalteu method as described by Boumerfeg et al. ${ }^{[4]}$.

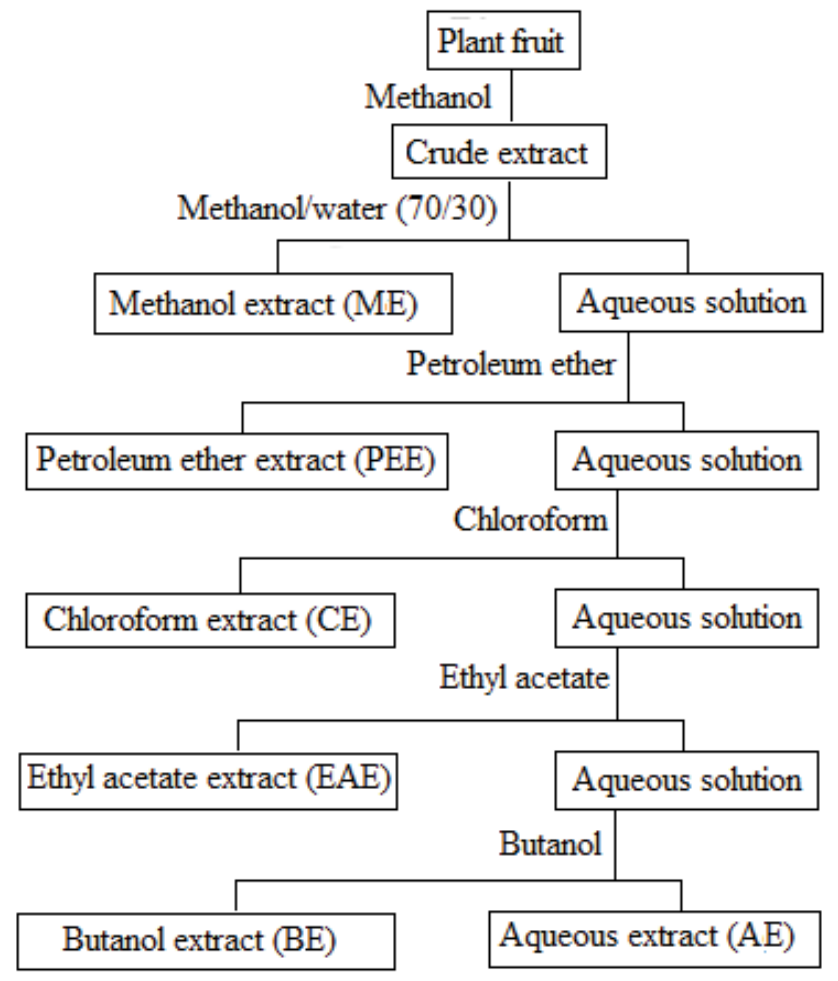

Fig. 1: Protocol for extraction of $F$. excelsior fruits
In brief, $100 \mu \mathrm{l}$ of extracts were well mixed with $0.5 \mathrm{ml}$ of the Folin-Ciocalteu stock reagent, $0.4 \mathrm{ml}$ of $0.75 \%$ $\mathrm{Na}_{2} \mathrm{CO}_{3}$ reagent was added after $4 \mathrm{~min}$ and incubated at room temperature for $1.5 \mathrm{~h}$. The absorbance of the mixture was measured at $760 \mathrm{~nm}$. The amount of total polyphenols was expressed as milligram of gallic acid equivalents per gram of extract. Flavonoids were quantified using $\mathrm{AlCl}_{3}{ }^{[11]}$. One milliliter of the extract or fraction was dissolved in methanol, $1 \mathrm{ml}$ of $2 \% \mathrm{AlCl}_{3}$ in methanol was added. After $10 \mathrm{~min}$ of incubation at room temperature the absorbance was measured at $430 \mathrm{~nm}$. The amount of flavonoids was expressed as milligram of quercetin and rutin equivalents per gram of extract.

\section{2,2'-diphenyl-1- picrylhydrazyl (DPPH) radical scavenging activity:}

The free radical scavenging activities of extracts were measured using DPPH test ${ }^{[11]}$. An equal volume of each extracts with different concentrations were added to methanol solution of DPPH and shaken vigorously at room temperature. After $30 \mathrm{~min}$, the absorbance was recorded at $517 \mathrm{~nm}$. Radical scavenging activity was expressed as the inhibition percentage and was calculated using the following Eqn., I \% $=\left(\mathrm{A}_{\text {blank }}-\right.$ $\left.\mathrm{A}_{\text {sample }} / \mathrm{A}_{\text {blank }}\right) \times 100$, where $\mathrm{A}_{\text {sample }}$ : absorbance of the sample, $A_{\text {blank }}$ : absorbance of the blank.

\section{B-Carotene-linoleate assay:}

Antioxidant capacity was determined by measuring the inhibition of the volatile organic compounds and conjugated diene hydroperoxides arising from linoleic acid oxidation. Emulsion $(2.5 \mathrm{ml})$ containing ß-carotene, linoleic acid and Tween-40, was added to $0.35 \mathrm{ml}$ of the sample then incubated for a total period of $48 \mathrm{~h}$ at room temperature. The absorbance of the mixture was measured at $490 \mathrm{~nm}$ after $0,1,2,4,6$, 24 and $48 \mathrm{~h}$ within the incubation period. The same procedure was repeated with a butyl hydroxytoluene (BHT), a synthetic antioxidant as positive control, and $\mathrm{MeOH}$ or $\mathrm{H}_{2} \mathrm{O}$ as negative blanks. The antioxidant activity (AA) of the extracts was evaluated as a percent of bleaching of $B$-carotene: $A A \%=\left(\mathrm{A}_{\text {sample }} / \mathrm{A}_{\mathrm{BHT}}\right) \times 100$, where $\mathrm{A}_{\text {sample }}$ is the compound absorbance and $\mathrm{A}_{\mathrm{BHT}}$ the absorbance of a sample with BHT ${ }^{[11]}$.

\section{Chelating activity on ferrous ions:}

Chelating activities of the extracts were assayed following the method reported by Dinis et al. ${ }^{[12]}$, with some modifications. Briefly, the solutions of samples $(250 \mu \mathrm{l})$ were initially mixed with $50 \mu \mathrm{FeCl}_{2}(11.9 \mathrm{mg}$ in $100 \mathrm{ml}$ of distilled water) and $450 \mu \mathrm{l}$ of methanol. 
After $5 \mathrm{~min}, 100 \mu \mathrm{l}$ of ferrozine $(12.3 \mathrm{mg}$ in $5 \mathrm{ml}$ of methanol) were added, the mixture was agitated then left to react during $5 \mathrm{~min}$ at room temperature thus allowing the formation of complex with a purple colour $\left(\mathrm{Fe}^{2+}\right.$ - ferrozine) having a maximum absorption at $562 \mathrm{~nm}$. EDTA was used as a positive control. The chelating activity of the test compound was calculated as follows, chelating activity $(\%)=\left[1-\left(\mathrm{A}_{\text {simple }}{ }^{-}\right.\right.$ $\left.A_{\text {control }}\right) \times 100$, where $A_{\text {sample }}$ : absorbance of the sample, $\mathrm{A}_{\text {control }}$ : absorbance of the control.

\section{Evaluation of antioxidant capacity by electrochemical techniques:}

The antioxidant capacity of samples was determined using an electrochemical method based on cyclic voltammetry techniques (Potentionstat Galvanostat Autolab, AUT7219). Cyclic voltammetry measurements were in an electrochemical cell with a volumetric capacity of $50 \mathrm{ml}$ containing a glassy carbon electrode as the working electrode, a platinum wire counter electrode and an $\mathrm{Hg} / \mathrm{Hg}_{2} \mathrm{Cl}_{2}$ reference electrode (saturated with $\mathrm{KCl}$ ). The potential was swept in inverse scanning mode starting from (-200 to $+800 \mathrm{mV}$ ) with a scanning rate of $25 \mathrm{mV} / \mathrm{s}$. The samples in the electrochemical cell were deaerated by purging with high purity nitrogen during the electrochemical measurements. The antioxidant capacity of the studied samples was determined. Ascorbic and gallic acids were used as standards in the calculation of antioxidant capacity ${ }^{[13]}$. The antioxidant capacity was calculated as follows: $\mathrm{AC}(\mathrm{g} / \mathrm{mg})=\mathrm{Ceq} / \mathrm{C}$, where, $\mathrm{AC}$ was the antioxidant capacity, $\mathrm{Ceq}$ was the equivalence concentration and $\mathrm{C}$ was the initial concentration.

\section{Antibacterial activity:}

The antibacterial activity of the extracts was tested against 9 bacterial species, Escherichia coli ATCC 25922, Pseudomonas aeruginosa ATCC 27853, Klebsiella pneumonia ATCC 700603, Salmonella typhimurium ATCC 13311, Acinetobacter baumanii ATCC 19606, Staphylococcus aureus ATCC 25923, Bacillus cereus ATCC 10876, Listeria monocytogenes ATCC 15313, Enterobacter faecalis ATCC 49452. Disc difusion technique was used to evaluate the antibacterial activity. Ten microlitres of each extract (dissolved at different concentrations in DMSO) on a disc of Whatman paper No. 1 was applied into MullerHinten medium inoculated with bacterial suspension at a concentration equivalent to $0.5 \mathrm{McFarland}$. The plates were incubated at $37^{\circ}$ for $48 \mathrm{~h}$ then the inhibition diameters were measured ${ }^{[14]}$.

\section{RESULTS AND DISCUSSION}

As an initial step of the phytochemical screening, the main groups of chemical constituents were qualitatively determined (Table 1). The results of F. excelsior extracts showed the presence of polyphenols, tannins, flavonoids, sterols/triterpenes, alkaloids and coumarins. The phytochemical analysis results of ethyl acetate, methanol, butanol, chloroform and aqueous extracts showed the presence of tannins (gallic and catechol tannins) and flavonoids, and the absence of coumarin. The presence of alkaloids was detected only in the methanol extract. The AA of phenolic compounds is mainly due to their redox properties, which can play an important role in absorbing and neutralizing free radicals. Flavonoids, tannins, phenolic acids, phenolic diterpenes, lignans and coumarins are the examples of phenolic components with antioxidant properties ${ }^{[15,16]}$. The result showed that the chloroform extract contained the highest amount of polyphenols $(0.109 \pm 0.001 \mathrm{~g}$ gallic acid equivalent, GAE/g) and the ethyl acetate extracts contained the highest amount of flavonoids $(0.010 \pm 0.0006 \mathrm{~g}$ quercetin equivalent $\mathrm{QE} / \mathrm{g}$; Table 2$)$.

Free radical scavenging activity of the extracts was tested using the DPPH method. The role of antioxidants is their interaction with oxidative free radicals. The essence of DPPH method is that the antioxidants react with the stable free radical, $\mathrm{DPPH}^{*}$ which has deep violet colour and convert it to DPPH-H, which has deep yellow colour. The degree of discoloration indicated the scavenging potential of the antioxidant sample. The DPPH activity of the extracts was increased in a dosedependent manner. The results presented in the fig. 2 showed that extract activity expressed as $\mathrm{IC}_{50}$ values were in the order ethyl acetate $>$ chloroform $>$ butanol $>$ methanol $>$ aqueous $>$ petroleum ether extract $(3722.5$

TABLE 1: PHYTOCHEMICAL SCREENING OF THE FRUIT EXTRACTS OF FRAXINUS EXCELSIOR

\begin{tabular}{|c|c|c|c|c|c|}
\hline & Alkaloids & $\begin{array}{c}\text { Gallic } \\
\text { Tannins }\end{array}$ & $\begin{array}{c}\text { Catechol } \\
\text { Tannins }\end{array}$ & Flavonoids & Coumarins \\
\hline $\begin{array}{c}\text { Whole } \\
\text { fruit }\end{array}$ & +++ & ++ & +++ & +++ & + \\
\hline$M E$ & + & ++ & ++ & ++ & - \\
\hline PEE & - & - & - & - & - \\
\hline CE & - & ++ & ++ & ++ & - \\
\hline $\mathrm{EAE}$ & - & +++ & ++ & +++ & - \\
\hline $\mathrm{BE}$ & - & ++ & ++ & + & - \\
\hline $\mathrm{AE}$ & - & ++ & ++ & + & - \\
\hline
\end{tabular}

ME: methanol extract; PEE: petroleum ether extract; CE: chloroform extract; EAE: ethyl acetate extract; $\mathrm{BE}$ : butanol extract; $\mathrm{AE}$ : aqueous extract 
$\mu \mathrm{g} / \mathrm{mg})$. In this study, the extracts and standard drugs reduced significantly the DPPH radical. AA might be related to the contents of phenolics and flavonoids compounds and confirmed the data of Ovedemi et al. ${ }^{[17]}$. The scavenger effect on the free radicals depends on the presence of free $\mathrm{OH}$ groups in particular $3-\mathrm{OH}$ on ring $\mathrm{C}$, with a configuration 3',4'-dihydroxyl on ring $\mathrm{B}$ in the polyphenols ${ }^{[18]}$.

The results of $\beta$-carotene bleaching method showed the same trend that of DPPH assay. In fact, the ethyl acetate extract of $F$. excelsior showed the highest AA with AA $\%=91.19 \pm 1.08$ (fig. 3). The difference in antioxidant activities of extracts of $F$. excelsior might be attributed to a difference in total polyphenols and/ or flavonoids contents. Several studies showed a correlation between AA and phenolics and flavonoids content ${ }^{[19]}$. Generally in the $\beta$-carotene bleaching method, linoleic acid produces hydroperoxides as free radicals during incubation. The presence of antioxidants in the extracts would minimize the oxidation of $\beta$-carotene by hydroperoxides ${ }^{[11]}$. This effect is due to inhibition of the peroxidation of the linoleic acid or to trapping of the radicals hydroperoxides formed during the linoleic acid oxidation.

Ferrous ion chelating activities of samples are shown in fig. 4. Ferrozine can quantitatively form complexes with $\mathrm{Fe}^{2+}$. In the presence of chelating agents, complex formation is disrupted, resulting in a decrease in the colour of the complex. Measurement of colour reduction therefore allows an estimation of the metal chelating activity. In this assay, the samples interfered with the formation of ferrous and ferrozine complexes, suggest that they have chelating activity and are able to capture ferrous ion before ferrozine. Because EDTA is a strong metal chelator, it was used as a standard in this study. Extracts or compounds with chelating activity are believed to inhibit lipid peroxidation by stabilizing transition metals, and form $\sigma$-bonds with metals ${ }^{[20]}$.

TABLE 2: TOTAL POLYPHENOL AND FLAVONOIDS CONTENTS OF FRAXINUS EXCELSIOR EXTRACTS

\begin{tabular}{lccc}
\hline & Polyphenols & \multicolumn{2}{c}{ Flavonoids } \\
\cline { 3 - 4 } & $(\mu \mathrm{g} \mathrm{GAE} / \mathrm{mg})$ & $\mu \mathrm{g}$ QE/mg & $\mu \mathrm{g}$ RE/mg \\
\hline ME & $109.19 \pm 1.67$ & $04.9 \pm 0.26$ & $08.06 \pm 0.45$ \\
$\mathrm{PEE}$ & $029.77 \pm 5.27$ & $01.12 \pm 0.03$ & $01.37 \pm 0.45$ \\
$\mathrm{CE}$ & $157.41 \pm 1.35$ & $05.1 \pm 0.05$ & $29.67 \pm 0.41$ \\
$\mathrm{EAE}$ & $047.75 \pm 1.54$ & $10.58 \pm 0.06$ & $16.44 \pm 0.60$ \\
$\mathrm{BE}$ & $065.30 \pm 1.06$ & $04.54 \pm 0.05$ & $06.84 \pm 0.40$ \\
$\mathrm{AE}$ & $039.51 \pm 0.53$ & $01.98 \pm 0.00$ & $02.83 \pm 0.00$ \\
\hline
\end{tabular}

ME: methanol extract; PEE: petroleum ether extract; CE: chloroform extract; EAE: ethyl acetate extracts; BE: butanol extract; $A E$ : aqueous extract; GA: gallic acid; Q: quercetin; R: rutin

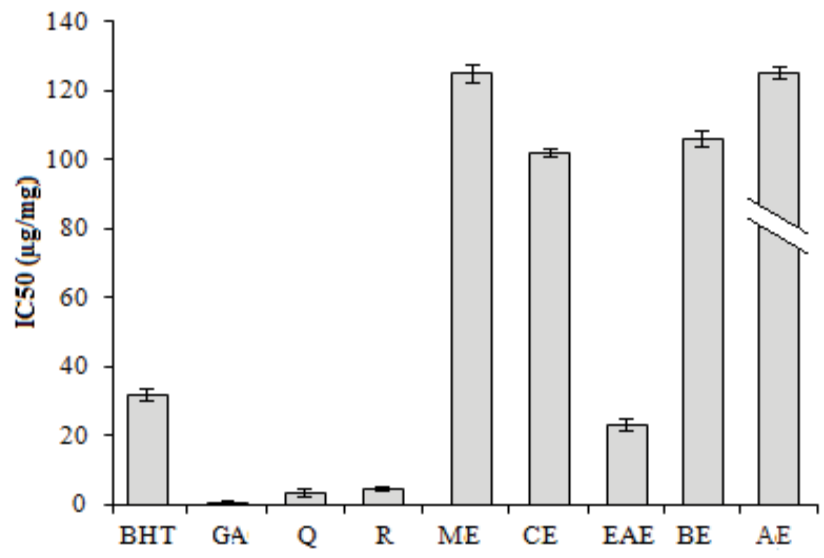

Fig. 2: $\mathrm{IC}_{50}$ of Fraxinus excelsior extracts

GA: gallic acid; Q: quercetin; R: rutin; BHT: butyl hydroxytoluene; ME: methanol extract; EAE: ethyl acetate extract; CE: chloroform extract; BE: butanol extract and $\mathrm{AE}$ : aqueous extract of $\boldsymbol{F}$. excelsior

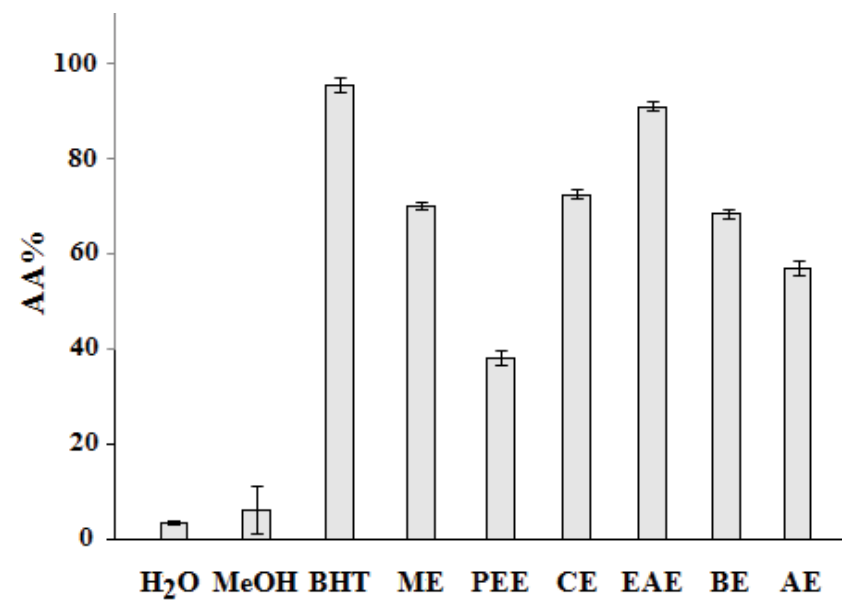

Fig. 3: Percent antioxidant activity of extracts of $F$. excelsior fruits

At $24 \mathrm{~h}$, ethyl acetate (EAE), chloroform (CE), butan-1-ol (BE), methanol (ME) and aqueous (AE) extracts

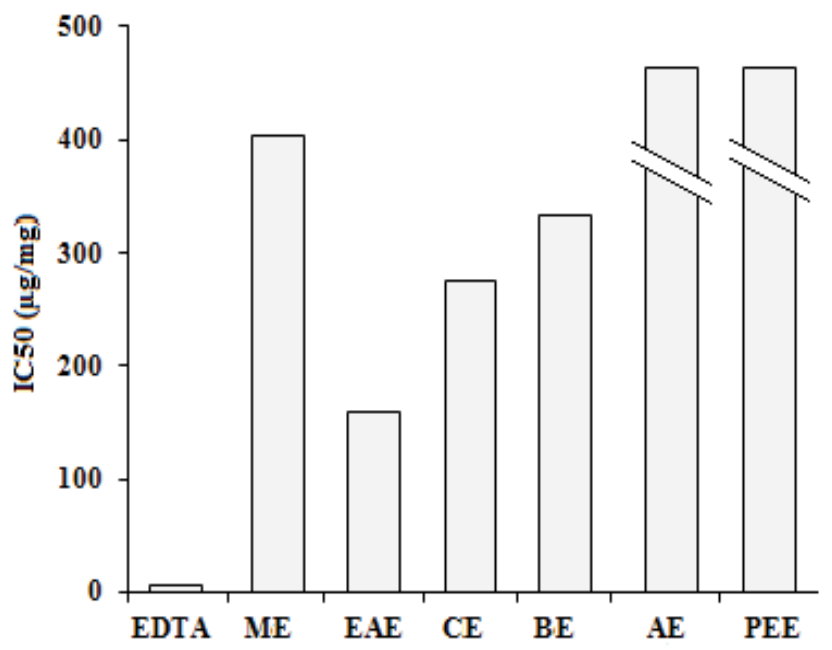

Fig. 4: Metal chelating activity of EDTA and extracts IC $_{50}$ of ethyl acetate extract (EAE), chloroform extract (CE), butan-1-ol extract (BE), methanol extract (ME), aqueous extract (AE) and petroleum ether extract (PEE) of $\boldsymbol{F}$. excelsior 
Excess of metal ions can lead to various anomalies in the body. The iron (II) chelating activity of plant extracts is of great significance, because it has been proposed that the transition metal ions contribute to the oxidative damage in neurodegenerative disorders like Alzheimer's and Parkinson's diseases ${ }^{[21]}$. The absorbance of $\mathrm{Fe}^{2+}$-ferrozine complex decreased by extracts in a dose-dependent manner. The capacity of the metal chelating of EDTA and extracts is presented in fig. 4. The petroleum ether extracts showed the lowest potential $(24.54 \pm 0.2 \mathrm{mg} / \mathrm{ml})$.

Many different spectroscopic methods can be used to measure the AA, with the DPPH approach as one of the most popular. Therefore, complementary methods that specifically present a different analytical principle for the same type of analysis are often recommended. In this context, the development of novel techniques to evaluate the AA is an area of interest of many research groups. Electroanalytical methods, mostly voltammetric techniques, represent one of these novel tools, presenting many advantages such as speed, low cost, simplicity and low consumption of reagents when compared to other methods. Another great advantage is the fact that they do not rely on the use of oxidizable compounds to measure the antioxidant capacity of the sample, but instead depend only on the inherent electrochemical properties of antioxidants in the sample ${ }^{[22]}$.
The cyclic voltammetry voltammograms obtained at different concentrations of ascorbic and gallic acids used as standards are shown in fig. 5. The voltammograms present typical irreversible oxidation processes. There is an increase in peak current with the increase in ascorbic and gallic acids concentrations, which leads to a linear relationship between these two parameters. The same irreversible electrochemical (no cathodic peak) was observed on inverting the scan direction, indicating the irreversibility of oxidation ${ }^{[13]}$ behaviour for $F$. excelsior extracts (fig. 6). The ethyl acetate fraction has the highest antioxidant capacity $(44.87 \pm 0.38 \mathrm{mg} / \mathrm{g} \mathrm{GAE}$ and $80.49 \pm 7.32 \mathrm{mg} / \mathrm{g} \mathrm{AAE})$. This capacity may be dependent mainly on the phenolic and flavonoid content. The Table 3 gathers the antioxidant capacity by electrochemical way of extracts.

The results obtained showed that the $F$. excelsior extracts (fig. 7, Table 4) possessed antibacterial activity, which varied with the type of the extract and also the type of the bacteria, Gram-positive or Gram-negative.

In conclusion, the AA of $F$ excelsior extracts collected from M'Sila was investigated. Different assays employed DPPH, B-carotene-linoleate system, chelating activity on ferrous ions and cyclic voltammetry, the application of electrochemistry an important means of characterizing many antioxidants.
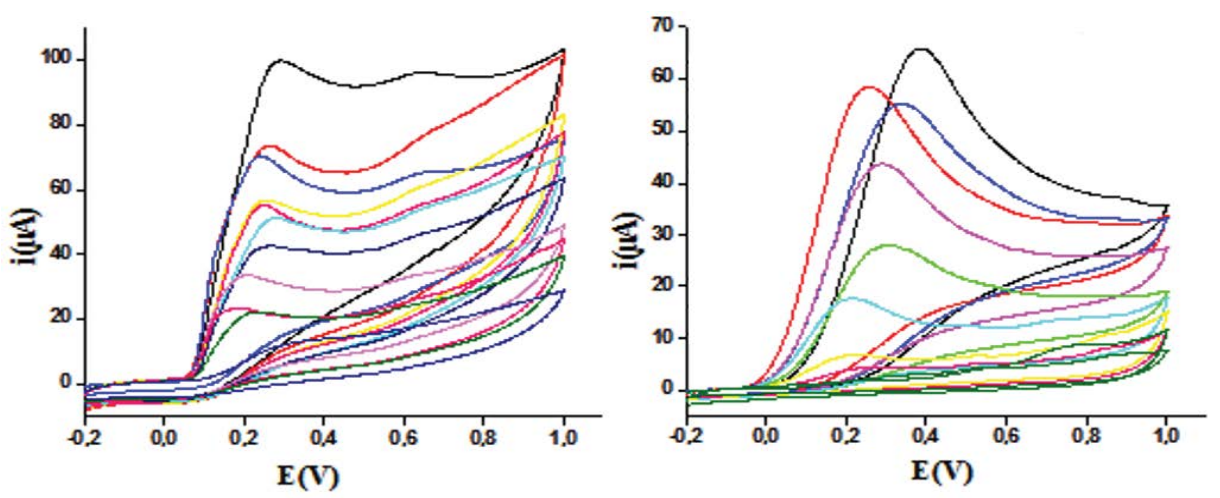

Fig. 5: Cyclic voltammograms of different concentrations of gallic and ascorbic acids

Cyclic voltammograms of different concentrations of (A) gallic and (B) ascorbic acid solutions in $0.1 \mathrm{~mol} / \mathrm{l} \mathrm{phosphate} \mathrm{buffer,} \mathrm{pH}-$ 7 containing $0.1 \mathrm{~mol} / \mathrm{l} \mathrm{NaCl}$ at a scan rate $25 \mathrm{mV} / \mathrm{s} \mathrm{A:}-10 \mathrm{mmol} / \mathrm{l} ;-8 \mathrm{mmol} / \mathrm{l} ;-6 \mathrm{mmol} / \mathrm{l} ;-4 \mathrm{mmol} / \mathrm{l} ;-2$ $\mathrm{mmol} / \mathrm{l} ;=1 \mathrm{mmol} / \mathrm{l} ;-0.8 \mathrm{mmol} / \mathrm{l} ; \longrightarrow 0.6 \mathrm{mmol} / \mathrm{l} ; \longrightarrow 0.4 \mathrm{mmol} / \mathrm{l} ; \longrightarrow 0.2 \mathrm{mmol} / \mathrm{l} ; \longrightarrow 0.1 \mathrm{mmol} / \mathrm{l} ; \mathrm{B}:-10 \mathrm{mmol} / \mathrm{l} ;$

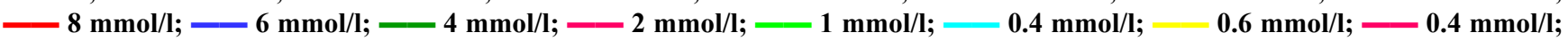
$0.2 \mathrm{mmol} / \mathrm{l} ;=0.1 \mathrm{mmol} / \mathrm{l}$

TABLE 3: ELECTROCHEMICAL ANALYSIS OF ANTIOXIDANT CAPACITY OF EXTRACTS OF FRAXINUS EXCELSIOR

\begin{tabular}{lcccccc}
\hline Fraction & ME & PEE & CE & EAE & BE & AE \\
\hline Eq. gallic acid & $06.83 \pm 0.16$ & -- & $07.30 \pm 0.00$ & $44.87 \pm 0.38$ & $05.22 \pm 0.00$ & -- \\
Eq. ascorbic acid & $16.16 \pm 2.28$ & -- & $21.50 \pm 2.49$ & $80.49 \pm 7.32$ & $16.67 \pm 0.61$ & -- \\
\hline An.
\end{tabular}

Antioxidant activity represented as $\mathrm{mg} / \mathrm{g}$ 

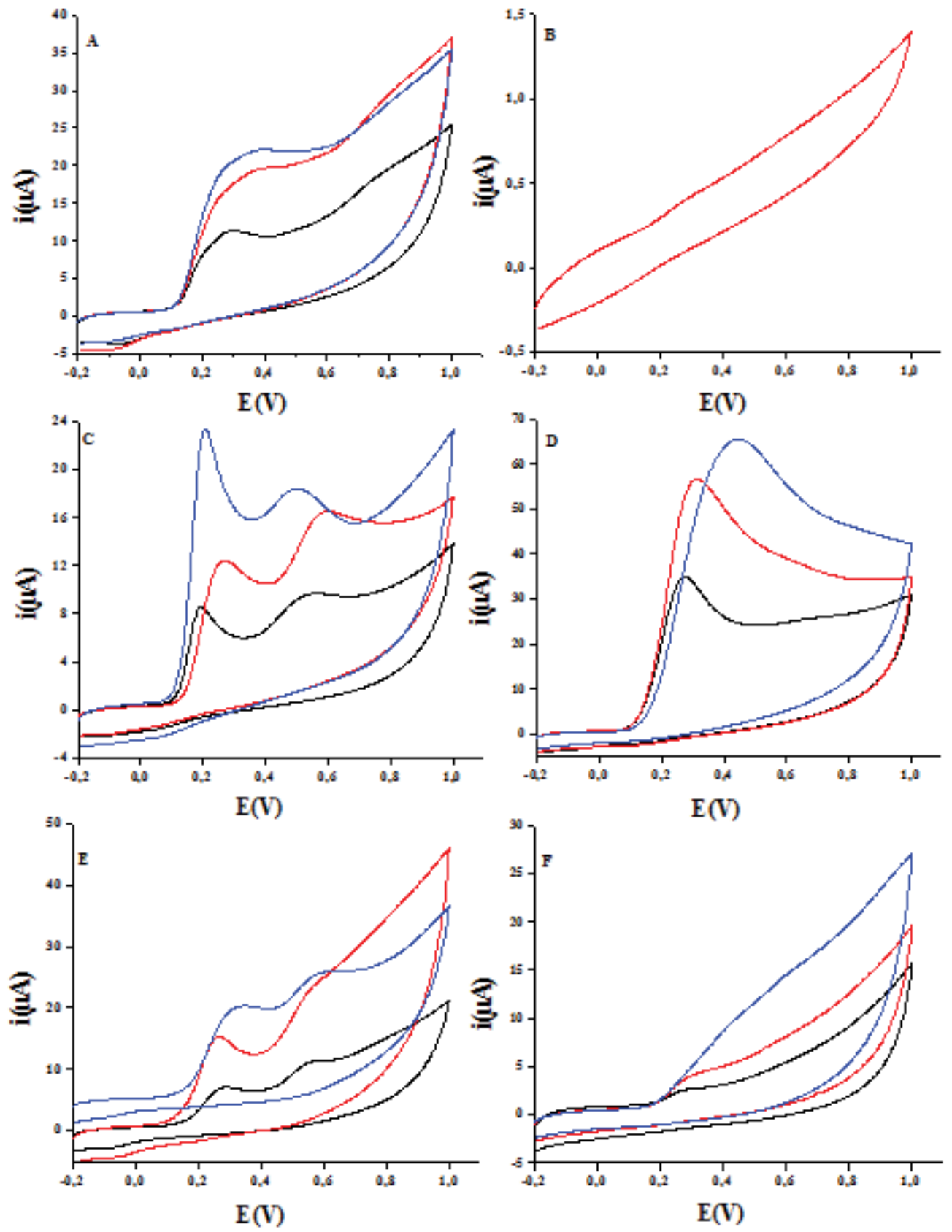

Fig. 6: Cyclic voltammograms

$\mathrm{A}: \mathrm{ME}=10 \mathrm{mg} / \mathrm{ml} ; \longrightarrow 20 \mathrm{mg} / \mathrm{ml} ;-30 \mathrm{mg} / \mathrm{ml} ; \mathrm{B}: \mathrm{PEE} \longrightarrow 200 \mathrm{mg} / \mathrm{ml} ; \mathrm{C}: \mathrm{CE} \longrightarrow 10 \mathrm{mg} / \mathrm{ml} ;-20 \mathrm{mg} / \mathrm{ml} ;-30 \mathrm{mg} / \mathrm{ml}$;

D: EAE $10 \mathrm{mg} / \mathrm{ml} ;-20 \mathrm{mg} / \mathrm{ml} ;-30 \mathrm{mg} / \mathrm{ml} ; \mathrm{E}: \mathrm{BE} \longrightarrow 10 \mathrm{mg} / \mathrm{ml} ; \longrightarrow 20 \mathrm{mg} / \mathrm{ml} ; \longrightarrow 30 \mathrm{mg} / \mathrm{ml} \mathrm{and} \mathrm{F:} \mathrm{AE} \longrightarrow 10$ $\mathrm{mg} / \mathrm{ml} ;-30 \mathrm{mg} / \mathrm{ml} ;-100 \mathrm{mg} / \mathrm{ml}$, in $\mathrm{pH}=7,0.1 \mathrm{M}$ phosphate buffer solution containing $0.1 \mathrm{M} \mathrm{NaCl}$ at scan rate $25 \mathrm{mV} / \mathrm{s}$

TABLE 4: ANTIBACTERIAL ACTIVITY INDICES OF EXTRACTS AGAINST BACTERIA

\begin{tabular}{|c|c|c|c|c|c|c|c|c|c|}
\hline \multirow[b]{2}{*}{ Extracts } & \multicolumn{5}{|c|}{ Gram-negative bacteria } & \multicolumn{4}{|c|}{ Gram-positive bacteria } \\
\hline & E. coli & $\begin{array}{c}P . \\
\text { aeruginosa }\end{array}$ & $\begin{array}{c}\text { K. } \\
\text { pneumonia }\end{array}$ & $\begin{array}{c}\text { S. } \\
\text { typhimurium }\end{array}$ & $\begin{array}{c}A . \\
\text { baumanii }\end{array}$ & S. aureus & B. cereus & $\begin{array}{c}E . \\
\text { faecalis }\end{array}$ & L. monocytogenes \\
\hline ME & 0.38 & 0.32 & 0.44 & 0.34 & 0.37 & 0.60 & 0.60 & 0.52 & 0.44 \\
\hline PEE & 0.38 & 0.32 & 0.44 & 0.34 & 0.4 & 0.32 & 0.48 & 0.40 & 0.36 \\
\hline CE & 0.28 & 0.33 & 0.36 & 0.42 & 0.36 & -- & 0.5 & 0.40 & 0.36 \\
\hline EAE & 0.34 & 0.34 & 0.36 & 0.44 & 0.34 & 0.38 & 0.56 & 0.48 & 0.34 \\
\hline $\mathrm{BE}$ & 0.32 & 0.28 & 0.34 & -- & 0.32 & -- & 0.44 & 0.38 & 0.28 \\
\hline $\mathrm{AE}$ & 0.26 & 0.26 & -- & --- & 0.34 & 0.28 & 0.38 & 0.40 & --- \\
\hline
\end{tabular}

ME: methanol extract; PEE: petroleum ether extract; CE: chloroform extract; EAE: Ethyl Acetate extract; BE: butanol extract; AE: aqueous extract 

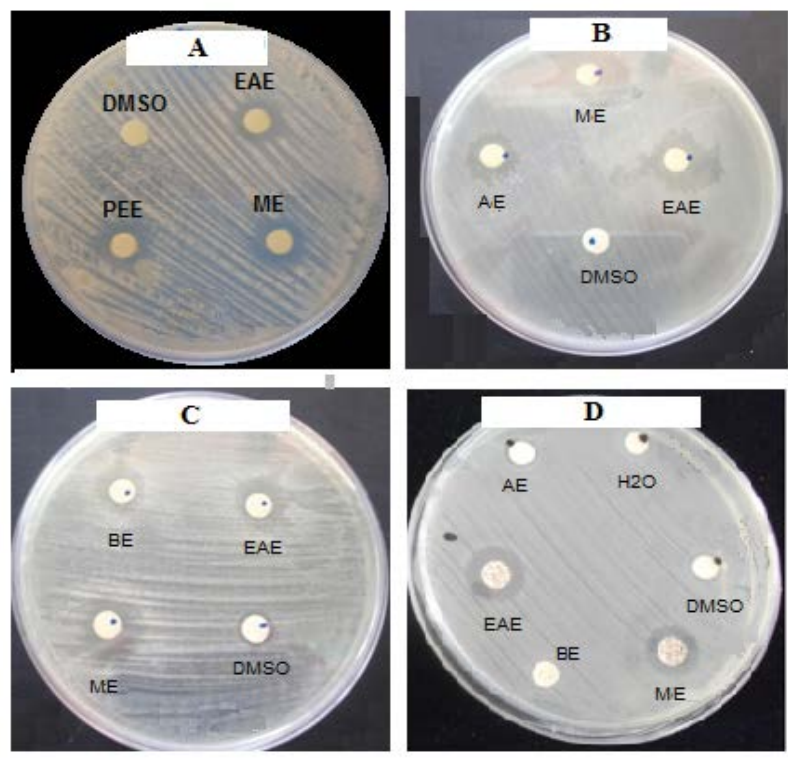

Fig. 7: Inhibition of the bacterial growth by $F$. excelsior extracts in the disc diffusion method

AE: aqueous extract, BE: butanol extract, EAE: ethyl acetate extract, ME: methanol extract, PEE: petroleum ether extract, DMSO: dimethyl sulfoxide. A: Escherichia coli; B: Bacillus cereus; C: Enterobacter faecalis; C: Salmonella typhimurium

All these methods showed that the AA depended mainly on the phenolic composition. These results also suggested that $F$. excelsior can serve as a potential source of bioactive compounds, which could be useful in the prevention/treatment of diseases where AA is needed. Bioautography would be used to determine the number of bioactive compounds in each extract ${ }^{[23]}$.

\section{Acknowledgements:}

This work was supported by the Algerian Ministry of Higher Education and Scientific Research (MESRS, DGRSDT) and by the Algerian Thematic Agency for Scientific Research in Health (ATRSS). We express our gratitude to these organizations. Authors thank Prof. H. Laouer, Department of Ecology and Vegetal Biology, Faculty of Nature and Life, University Ferhat Abbas Setif 1 for identifying and authentication of the collected plant material.

\section{REFERENCES}

1. Holmström MK, Finkel T. Cellular mechanisms and physiological consequences of redox dependent signalling. Nat Rev Mol Cell Biol 2014;15:411-21.

2. Fang YZ, Yang S, Wu G. Free radicals, antioxidants, and nutrition. Nutrition 2002;18:872-79.

3. Cheesman KH, Slater TF. An introduction to free radical biochemistry. Br Med Bull 1993;49:481-93.

4. Boumerfeg S, Baghiani A, Messaoudi D, Khennouf S, Arrar L. Antioxidant properties and xanthine oxidase inhibitory effects of Tamus communis L. root extracts. Phytother Res 2009;23:283-88.

5. Visen P, Saraswat B, Visen A, Roller M, Bily A, Mermet C, et al. Acute effects of Fraxinus excelsior L. seed extract on postprandial glycemia and insulin secretion on healthy volunteers. J Ethnopharmacol 2009;126:226-32.

6. Bai N, He K, Roller M, Lai C-S, Shao X, Pan M-H, et al. Secoiridoidglucosides from Fraxinus excelsior with effects on LPS-induced nitrite production in RAW 264.7 macrophages and human cancer cell lines. In: Juliani HR, Simon JE, Ho CT, editors. African natural plant products: Discoveries and Challenges in Chemistry, Health, and Nutrition. Vol. 2. Washington, DC: ACS Symposium Series, American Chemical Society; 2013. p.115.

7. Markham KR. Techniques of flavonoid identification. London: Academic Press; 1982. p. 133.

8. Bruneton J. Pharmacognosy, phytochemistry: medicinal plants (in French). Paris: Technique et Documentation-Lavoisier; 2009.

9. Sofowora A. Medicinal plants and traditional medicine in Africa. New Jersey: John Wiley \& Sons, Inc.; 1985.

10. Trease GE, Evans WC. Trease and Evans' Pharmacognosy. 15th ed. London: Saunders Publishers; 2002.

11. Baghiani A, Ameni D, Boumerfeg S, Adjadj M, Djarmouni M, Charef $\mathrm{N}$, et al. Studies of antioxidant and Xanthine oxidase inhibition potential of root and aerial parts of medicinal plants Capparis spinosa L. Am J Med Sci 2012;2:25-32.

12. Dinis TCP, Madeira VMC, Almeida LM. Action of phenolic derivatives (acetaminophen, salicylate and 5-aminosalycilate) as inhibitors of membrane lipid peroxidation and as peroxyl radical scavengers. Arch Biochem Biophys 1994;315(1):161-9.

13. Rebiai A, Lanez T, Belfar ML. Total polyphenol contents, radical scavenging and cyclic voltammetry of Algerian propolis. Int J Pharm Sci 2014;6:395-400.

14. Performance Standards for Anti-Microbial Susceptibility Testing. Available form: https://clsi.org/media/1469/ m100s27_sample.pdf.

15. Osawa T. Novel natural antioxidants for utilization in food and biological systems. In: Uritani I, Garcia VV, Mendoza EM, editors. Postharvest biochemistry of plant food materials in the tropics. Tokyo: Japan Scientific Societies Press; 1994. p. 241-51.

16. Pietta PG. Flavonoids in Health and Disease. In: Rice-Evans CA, Packer L, editors. New York: Marcel Dekker, Inc.; 1998. p. 61-110.

17. Ovedemi SO, Bradley $\mathrm{G}$, Afolavan $\mathrm{AJ}$. In vitro and in vivo antioxidant activities of aqueous extract of Strychonos henningsii Gilg. Afr J Pharm Pharmacol 2010;4:70-8.

18. Saha MR, Alam MA, Akter R, Jahangir R. In vitro free radical scavenging activity of Ixora coccinea L. Bangladesh J Pharmacol 2008;3:90-6.

19. Nagai T, Reiji I, Hachiro I, Nobutaka S. Preparation and antioxidant properties of water extract of propolis. Food Chem 2003;80:29-33.

20. Sun L, Zhang J, Lu X, Zhang L, Zhang Y. Evaluation to the antioxidant activity of total flavonoids extract from persimmon (Diospyros kaki L.) leaves. Food Chem Toxicol 2011;49:2689-96.

21. Aparadh VT, Naik VV, Karadge BA. Antioxidative properties (TPC, DPPH, FRAP, metal chelating ability, reducing power 
www.ijpsonline.com

and TAC) within some Cleome species. Ann Bot 2012;2:4956.

22. Mannino S, Brenna O, Buratti S, Cosi MS. A New Method for the evaluation of the 'Antioxidant Power' of wines. Electroanalysis 1998;10:908-912.
23. Elisha IL, Botha FS, McGaw LJ, Eloff JN. The antibacterial activity of extracts of nine plant species with good activity against Escherichia coli against five other bacteria and cytotoxicity of extracts. BMC Complement Altern Med 2017; 17:133. 